\title{
Decline of the North Sea houting: protective measures for an endangered anadromous fish
}

\author{
Niels Jepsen ${ }^{1, *}$, Michael Deacon $^{2}$, Anders Koed ${ }^{1}$ \\ ${ }^{1}$ DTU Aqua, Section for Freshwater Fisheries Ecology, Vejlsøvej 39, 8600 Silkeborg, Denmark \\ ${ }^{2}$ The Ministry of Environment, Nature Agency Ribe, Sorsigvej 35, 6760 Ribe, Denmark
}

\begin{abstract}
Once an abundant fish species in the rivers of the Wadden Sea in northwest Europe, the North Sea houting Coregonus oxyrinchus (NSH) was at the brink of extinction 25 yr ago. The very last stronghold for this species was in the small Danish River Vidaa. In an attempt to preserve this anadromous whitefish species, juveniles were hatchery-reared and stocked in 6 Danish rivers flowing into the Wadden Sea. These stocking efforts were fairly successful, and the houting established populations in at least 2 of the rivers, but the underlying problem of habitat degradation and migration obstacles was not solved. Since a national management plan was issued in Denmark in 2003, large-scale river restoration measures have been undertaken, including the removal of 13 large obstacles in $3 \mathrm{NSH}$ rivers and reestablishment of meanders in the lower river reaches. These measures were all intended to increase the spawning area for NSH and reduce juvenile mortality of NSH. The generic effect of these recent and ongoing changes is, however, not yet known. The NSH population has been irregularly monitored under various programs. Results from $15 \mathrm{yr}$ of field investigation using passive integrated transponder (PIT)-tagging showed that the NSH population in the River Vidaa remains stable, but in the other 2 rivers populations are decreasing. However, due to the recent physical improvements in river habitat and connectivity, we expect a substantial improvement in the population status of the NSH in the near future. Once they reach sexual maturity, NSH grow relatively slowly (mean: $2.55 \mathrm{~cm} \mathrm{yr}^{-1}$, ranging from 0 to $13.8 \mathrm{~cm} \mathrm{yr}^{-1}$ ) and can reach an age of 10 to $12 \mathrm{yr}$. The number of repeated recaptures year after year indicates low mortality for adult fish. Six individuals were recaptured in rivers other than the one in which they were initially PIT-tagged, indicating some exchange/straying between adjacent rivers. Overall there is a good chance that this unique species was saved in the 11th hour by intervention from managers and the EU.
\end{abstract}

KEY WORDS: North Sea houting $\cdot$ Coregonus $\cdot$ Anadromous $\cdot$ Habitat restoration $\cdot$ Wadden Sea

\section{INTRODUCTION}

The North Sea houting (NSH) is classified by traditional taxonomy as Coregonus oxyrinchus, and is a morphologically and ecologically divergent form of whitefish C. lavaretus. Its most prominent features are an elongated snout (Fig. 1) and its ability to tolerate oceanic salinities. Anadromy is a known trait within whitefish, involving migration into brackish environments such as estuaries and the Baltic Sea with salinities ranging from near 0 to approx. $20 \%$ (authors' pers. obs.). However, even adult whitefish do not tolerate salinity of $32 \%$ (Madsen et al. 1996), and yet juvenile NSH are able to move directly out into the North Sea, where salinity is approximately $33 \%$. In this paper we give a brief introduction to the $\mathrm{NSH}$, problems associated with it, and management issues. In particular, we present novel information on life history and migration, obtained through $15 \mathrm{yr}$ of field studies, including passive integrated transponder (PIT)-tagging, electro-fishing, and net surveys. These surveys were executed to monitor the status 

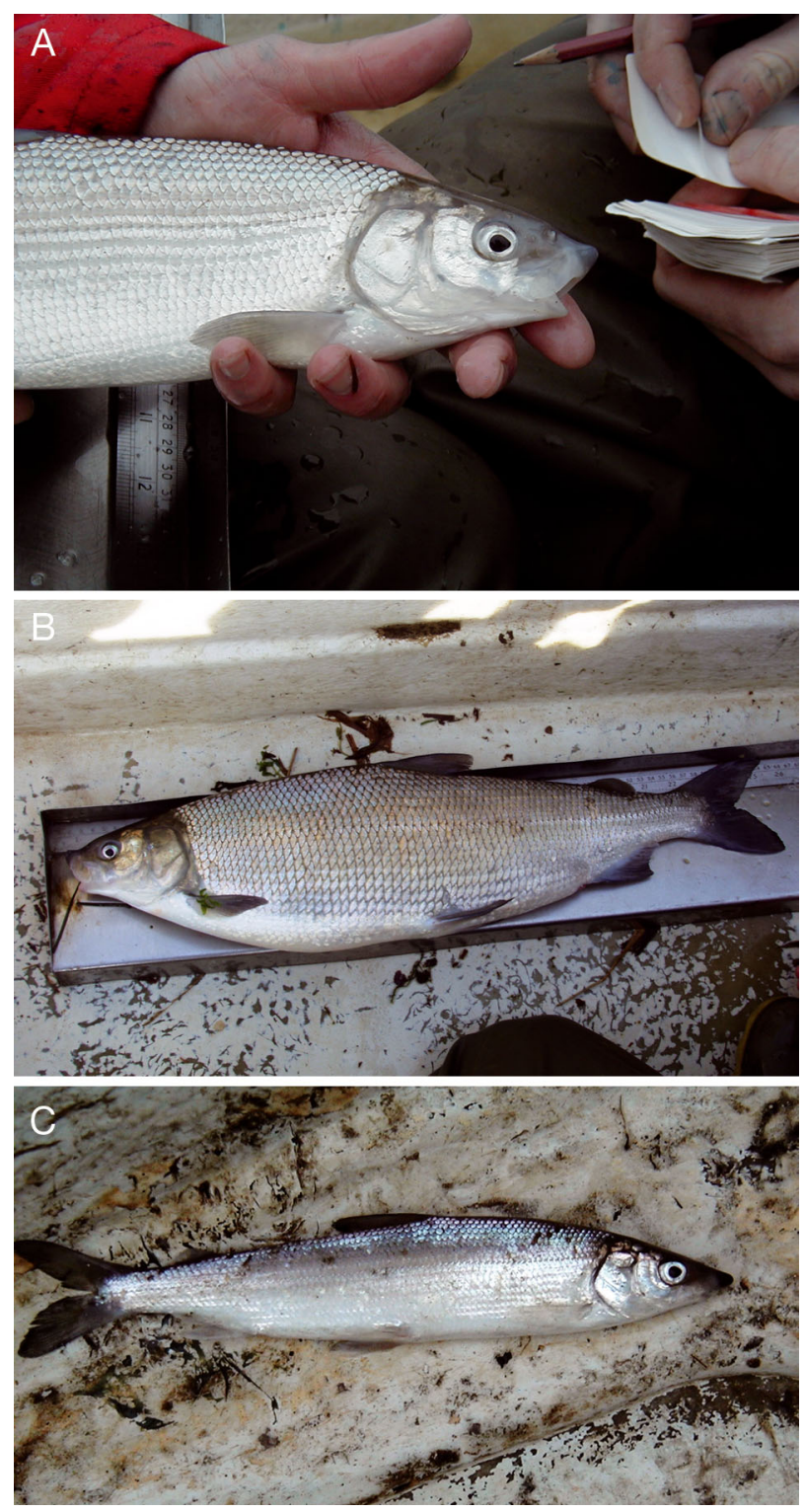

Fig. 1. Coregonus oxyrinchus. (a) Male, (b) mature female, and (c) juvenile North Sea houting

and development of NSH populations mainly in the Varde and Ribe Rivers and to obtain basic data on growth and survival of adult NSH.

\section{Biology of the NSH}

Population status

In the past NSH, was distributed throughout the Wadden Sea area, a coastal zone of the North Sea extending from southern Jutland to the Netherlands,

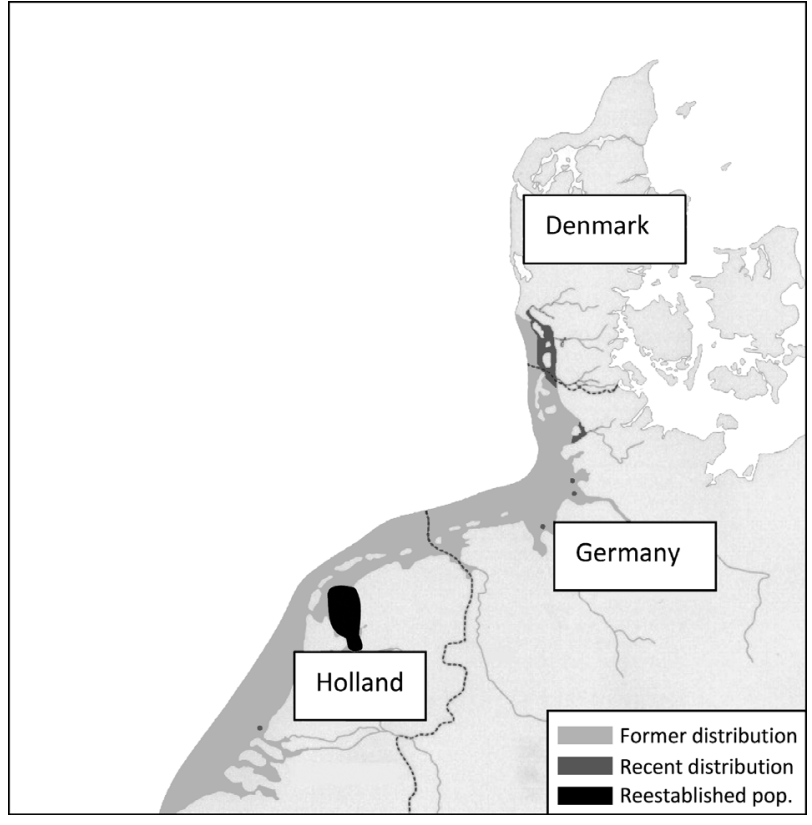

Fig. 2. Natural distribution of the Noth Sea houting (NSH). Recent studies suggest that NSH have now returned to the lower River Rhine (Borcherding et al. 2010)

characterized by extensive tidal flats (Fig. 2). The houting spawned in many of the region's rivers, including major rivers such as the Rhine and the Elbe. Until 1900, commercial fishers landed up to $15 \mathrm{t}$ of NSH annually in the lower Rhine (Borcherding et al. 2008). Only one indigenous population of NSH remains in the world, and this last population is located in the Danish River Vidaa. Fish from the Vidaa have been used as broodstock for reintroduction of NSH in other rivers (Borcherding et al. 2010).

For many coregonid fishes, the taxonomy to date remains controversial (Hansen et al. 2008), and there is no conclusive documentation that NSH and common whitefish Coregonus lavaretus are 'true' biological species (i.e. show reproductive isolation in sympatry; Hansen et al. 2006). However, the NSH, with its special adaptations to high salinity, should qualify as an evolutionarily significant unit (see discussion in Hansen et al. 1999). Regardless of taxonomic discussions, the NSH is widely accepted and managed as a unique species. The effective population size $(\mathrm{Ne})$ estimated from genetic analyses was found to be 577 in the River Vidaa and appeared stable (1980 to 2000), with indications of previous bottlenecks (Hansen et al. 2006). A survey in 2000 estimated the NSH spawning population of the River Vidaa to be around 4000 individuals, and the total Danish population to be 6000 to 7000 adults (Jensen et al. 2003). 
Life history

Due to the limited distribution and small population size of NSH, only few studies have been performed, and specific knowledge of behavior and life history of the species in Danish rivers is limited. A summary is presented below.

In early winter, adult NSH (35 to $60 \mathrm{~cm}$ ) ascend the larger watercourses to spawn. Only rivers with free passage can be used for spawning, as even small weirs and dams block the passage of NSH to upriver spawning areas. Fish ladders and small or steep bypass streams do not seem to work for NSH, and there is no evidence of spawning upstream of even small obstacles (Jensen et al. 2003). Spawning sites are characterized by a stream width of 4 to $10 \mathrm{~m}$, medium water velocity, a firm bed (gravel or coarse sand), and abundant macrophytes (Jensen et al. 2003). The spawning period normally lasts for 2 to $3 \mathrm{wk}$ in November to December (Jensen et al. 2003). The small adhesive eggs are spawned freely into the water where they become attached to aquatic plants, rocks or gravel (Muus \& Dahlstrøm 1990). NSH can return to spawn in the streams several times during their relatively long (10 to $12 \mathrm{yr}$ ) lifespan (Borcherding et al. 2008, present study). The eggs hatch in February to March. At the early stage, the approximately $1 \mathrm{~cm}$ long fry cannot survive salinity levels as high as those in the Wadden Sea (Jensen et al. 2003). Newly hatched fry are carried downstream with the current (Borcherding et al. 2006), so their survival depends on being carried into areas of lentic water, such as flooded meadows, reedbeds, small impoundments, large river bends, or similar areas which constitute the natural rearing grounds, where the juveniles feed mainly on zooplankton (Borcherding et al. 2006). In a laboratory study, well fed juveniles spent more time in refuges, but dispersed earlier than fooddeprived conspecifics (Poulsen et al. 2010). When the fry reach a length of 3 to $4 \mathrm{~cm}$, after about $2 \mathrm{mo}$, they can tolerate full salt levels and migrate/drift out into the sea (Rasmussen 2004). After 1 to 2 (males) or 3 to 4 (females) seasons at sea, they reach adult size and join the spawning population (Borcherding et al. 2006). Immature NSH have been observed in the lower parts of rivers during winter (Jensen et al. 2003), much like the 'finnocks', immature sea trout Salmo trutta overwintering in rivers. If par- tial migration of NSH exists (i.e. part of the population does not migrate to sea), fish would be encountered in the rivers during summer, but no reports/observations of adult NSH in the rivers during summer have been made. After becoming sexually mature, the growth rate of NSH decreases, and even old (>10 yr) individuals rarely reach lengths of more than $60 \mathrm{~cm}$ (present study).

\section{MANAGEMENT AND RESTORATION MEASURES}

\section{Management}

Centuries of habitat degradation, loss of river connectivity, and pollution have collectively contributed to the decline of the NSH. Indeed, in 1980 the species was only found in 1 small Danish stream. In 1983, NSH were listed as protected in Denmark, and all fishing for the species was banned. In 1988, the species was listed in the Bern Convention and was classified as critically endangered in the EU Habitats Directive in 1992. A survey of the fishing activities in the Danish Wadden Sea in 1994 to 1997 estimated that annually 800 adult and 2600 juvenile NSH were captured as unintentional by-catch in the fyke net fishery. Most of these fish died after being discarded (Anonymous 1997). In 1999, strict regulations (i.e. closed season, closed areas, limited number of nets) were implemented on this fishery, decreasing the loss of NSH. When the NSH population was at its lowest level in the late 1980s, supportive breeding and stocking took place, and 1.7 million juveniles $(4-6 \mathrm{~cm})$ were released into 6 rivers (Table 1). This gave a boost to the population in most of the rivers, suggesting that spawning success or survival at the early juvenile stage were the key limiting factors for the population. Lack of access to upriver spawning areas in combination with river regulations causing relatively high velocity and lack of lentic habitats

Table 1. Coregonus oxyrinchus. Stocking of juvenile North Sea houting in 6 Danish rivers. In total, over 1.7 million fish were stocked. (-) Years in which no stocking took place

\begin{tabular}{|rrrccrr|}
\hline Year & Varde & Sneum & Kongeaa & Ribe & Brede & Vidaa \\
\hline 1987 & 5000 & - & - & 27500 & 3000 & 30500 \\
1988 & 29400 & 47500 & 20000 & 90800 & 62000 & 189000 \\
1989 & 32400 & 23600 & 22500 & 131800 & 77000 & 99000 \\
1990 & 21200 & 10200 & 10200 & 64800 & 44500 & 68500 \\
1991 & 29000 & 25000 & 41000 & - & 42000 & 58000 \\
1992 & 105000 & 72500 & 45000 & - & 60000 & 154000 \\
Total & 222000 & 178800 & 138700 & 314900 & 288500 & 599000 \\
\hline
\end{tabular}


likely resulted in very low juvenile survival due to premature entry into salt water.

The remaining Danish NSH population is now subject to a large-scale rehabilitation program, involving habitat restoration and removal of migration obstacles in rivers flowing into the Danish Wadden Sea. $\mathrm{NSH}$ have also been reintroduced into Dutch and German rivers in the North Sea area (DeGroot \& Nijssen 1997, Kranenbarg et al. 2002, Borcherding et al. 2010).

\section{EU-supported NSH restoration project}

The conservation of NSH became a matter of considerable European interest, and in 2005 an ambitious restoration project with a total project budget of 13.4 million euros was initiated. The EU Life Program granted 8 million euros, thus financing most of the project. The project focuses on addressing the lack of adult upstream passage and lack of juvenile rearing habitat. In Denmark, only a few small-scale hydropower facilities block the rivers, but several hundred traditional trout farms are located along the rivers, and use weirs to divert flow into the basins, thus blocking upstream, and to some degree downstream, migration of most fish species.

The overall project objective is to restore and maintain a favorable conservation status for $\mathrm{NSH}$ in 4 Danish river systems: Vidaa, Varde, Ribe and Brede. In the second phase of the project, 3 additional rivers (Sneum, Kongeaa and Brons) will also be restored. Weirs and dams have been removed to facilitate upand downstream migration. Two hydroelectric power plants and 11 other weirs (fish farms) have been removed. Channelized river sections have been reengineered (e.g. by addition of natural channel elements such as meanders) and enriched with rocks and pebbles, creating new spawning areas. A combination of changes in hydrology and construction works created new flooded nursery areas for fry adjacent to the river. To summarize, the projects that have been carried out are intended to: enable NSH to reclaim $120 \mathrm{~km}$ of river habitats by the removal of 13 man-made obstacles in 3 river systems; establish 470 ha of new nursery area; re-engineer $21 \mathrm{~km}$ of heavily modified river; remove fish farms to improve survival of drifting fry in $75 \mathrm{~km}$ of spawning habitat (formerly upstream of the fish farms); and if necessary, use supportive breeding to safeguard the total gene pool and ensure viable populations until these become self-sustaining. Furthermore, the project is expected to have a profound and positive effect on numerous other components of the river ecosystems. Other rare species in the rivers will likely benefit considerably from the changes, including salmon Salmo salar, sea trout Salmo trutta, sea lamprey Petromyzon marinus, and freshwater pearl mussel Margaritifera margaritifera. The project was planned and implemented by the relevant national and regional authorities in cooperation with a number of stakeholders including land and fish-farm owners, regional angling societies, and owners of hydrological installations.

\section{ELECTROFISHING AND NET SURVEYS}

\section{Surveys}

In the period from 1994 to present (2011), electrofishing and net surveys were carried out in 4 rivers (Table 2) to catch and tag adult NSH during their spawning migration. The purpose of these surveys was to monitor the development of the spawning stock. The surveys were carried out by different agencies and for the most part were not standardized (Table 2). All sampling/fishing was done in the lower parts of the rivers. Data from extensive annual routine electrofishing for salmon and sea trout indicate that the NSH do not pass even modest obstacles (passable for salmonids), and thus NSH mainly spawned in the lower parts of the rivers.

\section{Tagging methods}

From 2000 onwards, adult NSH were caught by electrofishing from boats using hand-held anodes. Fish were netted, sedated in a bath of benzocaine, measured (total length, TL), and finally an $11 \mathrm{~mm}$ passive integrated transponder (PIT) tag was injected into the dorsal musculature. This procedure lasts about $1 \mathrm{~min}$, and all fish were released within $1 \mathrm{~h}$ after capture. From 1994 to 1999, fish were externally marked with injected Alcian blue dye (PanJet). Recaptured fish were scanned for PIT identification, measured (TL), and recorded.

In the River Ribe, annual net fishing and electrofishing surveys have been performed since 1994 and thus provide standardized data on the development of the spawning population in this river. From 2006 to 2011, we standardized catch per unit effort data from gill-netting in the River Ribe. In the other rivers, sampling has been more sporadic (Table 2), thus the data from the Ribe are used for most long-term analyses. 


\section{Results}

Since 2000, a total of 1764 adult NSH have been caught and PIT tagged. Based on $283 \mathrm{NSH}$ from the River Ribe, the sex distribution was $80 \%$ male (35$60 \mathrm{~cm}$ ) and $20 \%$ female $(38-62 \mathrm{~cm})$. Several PITtagged fish were recaptured, which provided a rough estimate of survival and repeat spawning. Out of the
1764 tagged NSH, 506 were recaptured; of these, 339 were caught in the following seasons (>250 d after tagging). Some PIT-tagged NSH were recaptured several times. Most notably, a male fish tagged in 2001 was recaptured 10 times over a $4 \mathrm{yr}$ period. A total of 6 PIT tagged fish were later recaptured in other rivers.

The mean growth rate of 339 recaptured $\mathrm{NSH}$ was $2.55 \mathrm{~cm} \mathrm{yr}^{-1}$, ranging from 0 to $13.8 \mathrm{~cm} \mathrm{yr}^{-1}$ (Fig. 3),

Table 2. Coregonus oxyrinchus. Overview of the available results from North Sea houting (NSH) surveys in 4 rivers. NSH were caught by electro-fishing (EF) and in fyke- and gill nets. Estimates were calculated based on tagged, recaptured fish. ne: no estimate

\begin{tabular}{|c|c|c|c|c|c|c|c|c|}
\hline \multirow[t]{2}{*}{ Year } & \multicolumn{2}{|c|}{ Varde } & \multicolumn{2}{|c|}{ Sneum } & \multicolumn{2}{|c|}{ Ribe - } & \multicolumn{2}{|c|}{ Vidaa } \\
\hline & Method & $\begin{array}{l}\text { Catch/ } \\
\text { estimate }\end{array}$ & Method & $\begin{array}{l}\text { Catch/ } \\
\text { estimate }\end{array}$ & Method & $\begin{array}{l}\text { Catch/ } \\
\text { estimate }\end{array}$ & Method & $\begin{array}{l}\text { Catch/ } \\
\text { estimate }\end{array}$ \\
\hline 1994 & EF/Fyke & $17 / \mathrm{ne}^{\mathrm{a}}$ & EF/Net & $43 /$ ne $^{a}$ & EF/Net & $1258 / 9189$ & EF & $440 / \mathrm{ne}^{\mathrm{b}}$ \\
\hline 1995 & EF/Fyke & $32 / \mathrm{ne}^{\mathrm{a}}$ & EF/Net & $92 / 301$ & EF/Net & $688 / 5379$ & EF/Fyke & $587 / 2097$ \\
\hline 1996 & EF/Fyke & $94 / 780$ & EF/Net & $85 / 166$ & EF/Net & $467 / 2159$ & EF & $653 / \mathrm{ne}^{\mathrm{b}}$ \\
\hline 1997 & EF/Fyke & $106 / 419$ & EF/Net & $47 / 132$ & EF/Net & $357 / 1995$ & $\mathrm{EF}$ & $475 / \mathrm{ne}^{\mathrm{b}}$ \\
\hline 1998 & EF/Fyke & $129 / 1802$ & EF/Net & $52 / 171$ & EF/Net & $286 / 1650$ & $\mathrm{EF}$ & $825 / n e^{b}$ \\
\hline 1999 & EF/Fyke & $112 / 533$ & EF/Net & $35 / 77$ & EF/Net & $164 / 1308$ & $\mathrm{EF}$ & $716 / \mathrm{ne}^{\mathrm{b}}$ \\
\hline 2000 & EF/Fyke & 90/552 & EF/Net & $7 / \mathrm{ne}^{\mathrm{a}}$ & EF/Net & $141 / 1712$ & $\mathrm{EF}$ & $568 / \mathrm{ne}^{\mathrm{b}}$ \\
\hline 2001 & EF/Fyke & $73 / \mathrm{ne}^{\mathrm{a}}$ & EF/Net & $1 / \mathrm{ne}^{\mathrm{a}}$ & EF/Net & $107 / 675$ & $\mathrm{EF}$ & $302 / \mathrm{ne}^{\mathrm{b}}$ \\
\hline 2002 & EF/Fyke & $79 / \mathrm{ne}^{\mathrm{a}}$ & & & EF/Net & $103 / 432$ & $\mathrm{EF}$ & $288 / \mathrm{ne}^{\mathrm{b}}$ \\
\hline 2003 & EF/Fyke & $53 /$ ne $^{a}$ & & & EF/Net & 79/779 & EF & $204 / \mathrm{ne}^{\mathrm{b}}$ \\
\hline 2004 & EF/Fyke & $89 / 530$ & & & EF/Net & $90 / 496$ & EF & $246 / n e^{b}$ \\
\hline 2005 & EF/Fyke & $90 / 527$ & & & EF/Net & $140 / 1287$ & $\mathrm{EF}$ & $330 / \mathrm{ne}^{\mathrm{b}}$ \\
\hline 2006 & & & & & CPU_Net & $41 / 670$ & EF/Net & $259 /$ ne $^{a}$ \\
\hline 2007 & & & & & CPU_Net & $30 / 476$ & EF/Net & $182 / \mathrm{ne}^{\mathrm{a}}$ \\
\hline 2008 & & & & & CPU_Net & $214 / 3218$ & & \\
\hline 2009 & & & & & CPU_Net & $123 / 1862$ & & \\
\hline 2010 & & & & & CPU_Net & $51 / 789$ & & \\
\hline
\end{tabular}

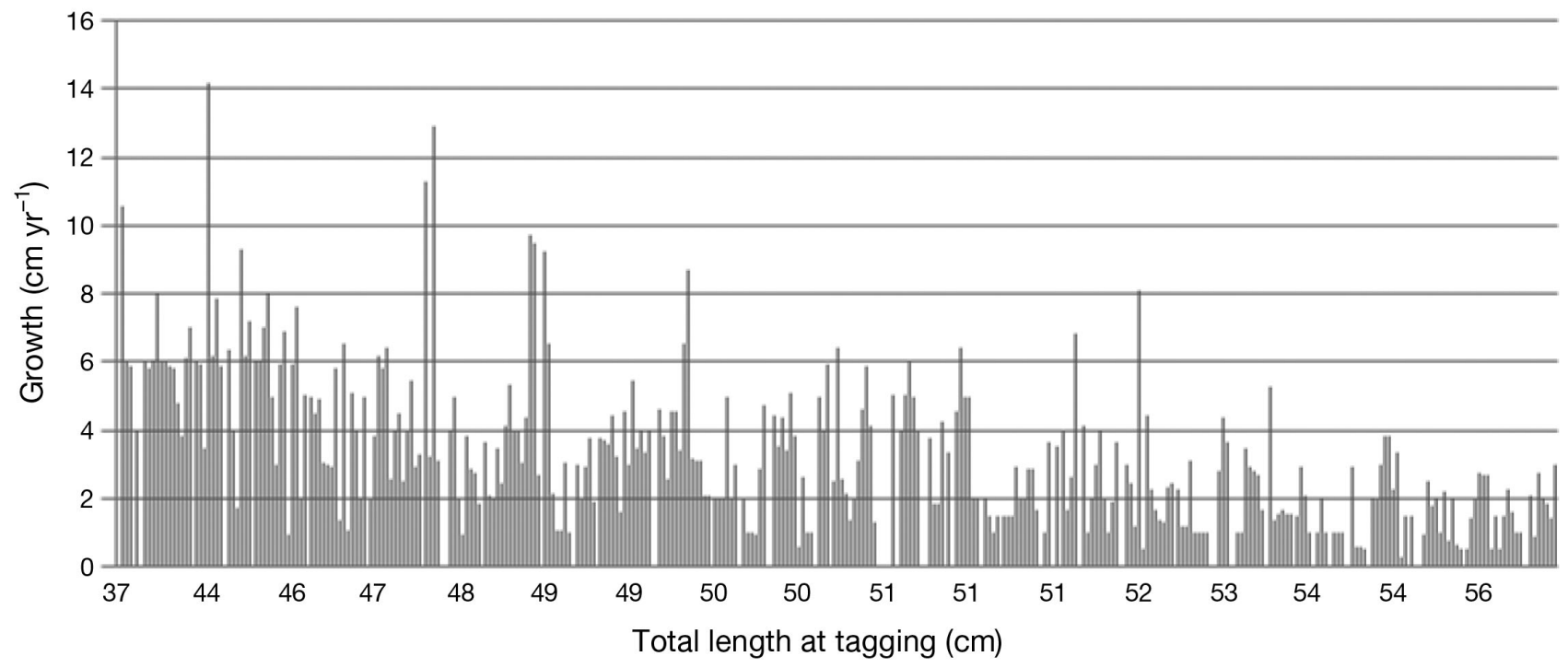

Fig. 3. Coregonus oxyrinchus. Growth of 339 North Sea houting recaptured in the Ribe, Varde or Vidaa $230-2500 \mathrm{~d}$ after tagging 

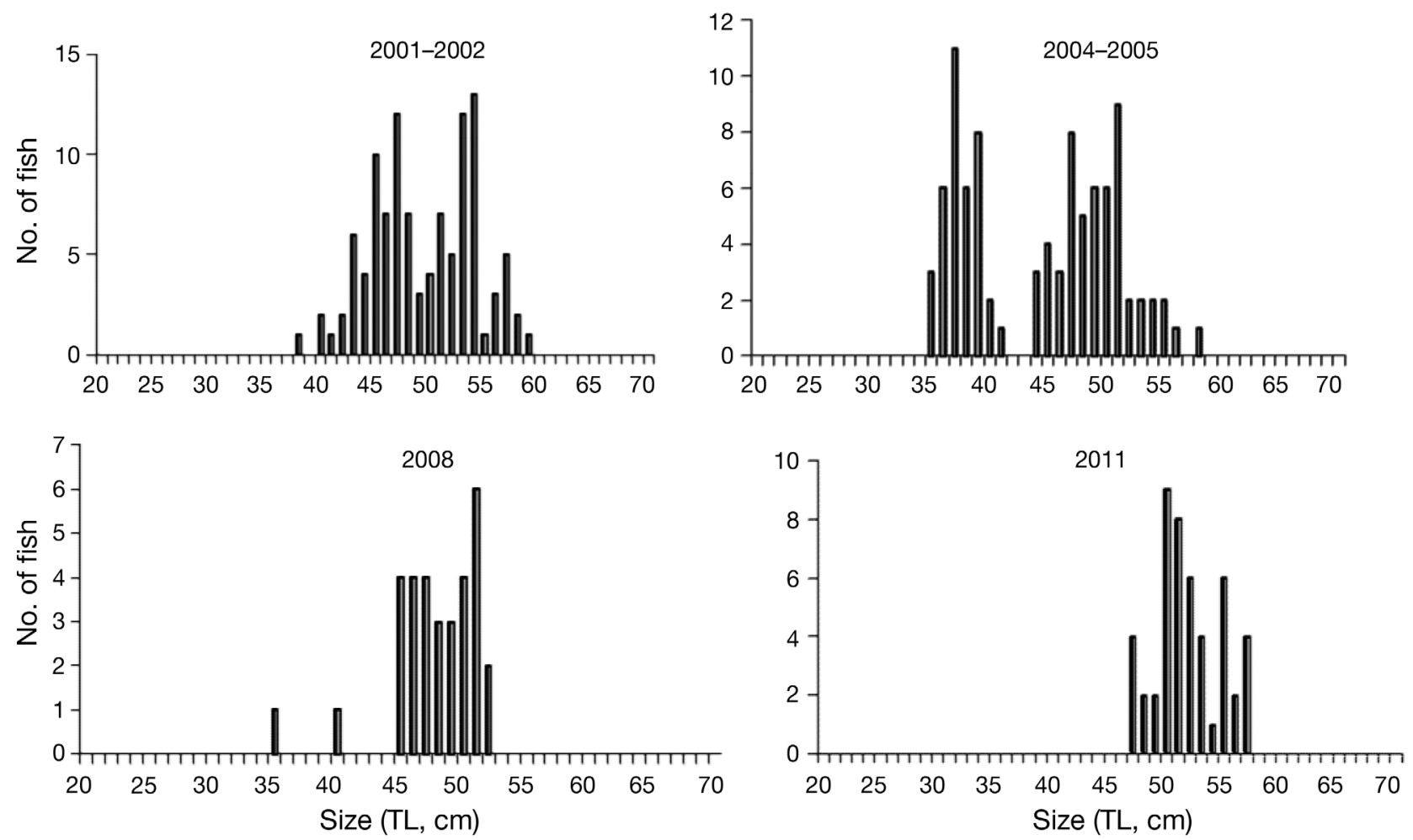

Fig. 4. Coregonus oxyrinchus. Size distribution $(\mathrm{TL}, \mathrm{cm})$ of North Sea houting, sampled in the River Ribe during the last decade

with larger, sexually mature individuals showing slow or no growth. The Varde, Ribe, and Vidaa Rivers still host populations of NSH (Table 2), but they are small and exhibit low or highly variable recruitment (Fig. 4).

\section{DISCUSSION}

The age (and size) distributions of the stocks reveal that adult survival is high, but recruitment is very limited. The skewed sex ratio is consistent over years and between different rivers and is most likely a consequence of males maturing earlier and spending more time in the spawning areas than females, thus being more catchable. The actual spawning event has been reported to involve 1 female spawning with a group of males, simultaneously releasing eggs and sperm to secure fertilization of the many eggs (Grøn 2005). The fact that adult (or juvenile) NSH have rarely been observed more than $10 \mathrm{~km}$ upstream from the sea is more likely a consequence of the problems with impassable obstacles than preference, so the reestablishment of connectivity should greatly improve condi- tions for NSH. The recorded growth of tagged NSH shows quite large individual variation, but generally a fast early growth that decreases with age. Borcherding et al. (2006) found that juvenile NSH in ponds grew $0.6 \mathrm{~mm} \mathrm{~d}^{-1}$, whereas the fastest growth we observed for adult NSH was $0.4 \mathrm{~mm} \mathrm{~d}^{-1}$, and the mean growth was only $0.07 \mathrm{~mm} \mathrm{day}^{-1}$.

The fact that almost $20 \%$ of the tagged fish were recaptured in seasons following tagging indicates high $(>20 \%)$ adult year-to-year survival and probably some spawning site fidelity. With catch efficiency of the sampling estimated at 20 to $30 \%$, the adult year-to-year survival may be as high as $80 \%$. The recapture of 6 PIT-tagged fish in other rivers indicates some exchange between rivers. A similar pattern is seen in salmon populations, where some individuals stray to non-natal streams to spawn. This is important in terms of restoration of populations because such exchange will facilitate colonization of new suitable habitat such as restored river systems.

In the River Ribe, the annual surveys (Fig. 4) show apparent successful spawning or good juvenile survival in 2003/04, providing recruitment to the spawning stock in the following years. However, since that 
time, recruitment has failed, and in 2011 only old individuals were captured (Fig. 4). This pattern of very sporadic recruitment seems to be rather general. Stable recruitment occurs only in the River Vidaa, whereas in the other rivers, several cohorts are missing. Moreover, in the Rivers Sneum, Brede, and Konge, NSH reproduction apparently failed, and when the last of the stocked individuals died, they were extirpated. The management plan is based upon a general hypothesis that the population bottleneck is mortality due to premature entry of juveniles into salt water. This may be true, but has not yet been confirmed, so the problem could also be a lack of spawning success. Monitoring is now carried out to estimate the number of drifting juveniles in the early summer and thus provide some information on spawning success.

The overall status at present is that the reintroduction of NSH has failed in 3 of the rivers, and a population was established in 2 rivers, although it remains vulnerable/threatened due to sporadic recruitment. The original NSH population remains at a relatively stable level only in the River Vidaa.

The history of the decline of the NSH is not unique, but represents the fate of hundreds of fish species globally that are threatened by human activity. In the case of the NSH, however, the 11thhour intervention may have secured a future for the species and thus avoided further loss of biodiversity in the Wadden Sea ecosystem. The local cooperation among researchers, managers, and stakeholders provided the opportunity to design and carry out an ambitious restoration project with financial aid from the EU-LIFE program. Consensus regarding the main problems, based on limited documentation, was crucial for the success of the project. The design, planning, and practical execution of such a project was costly and time consuming. For example, the buy-out of fish farms and the breaching of weirs and dams involved both diplomacy and long negotiations and resulted in some delay. The most drastic outcome of the project was the restoration of the River Varde, where a hydropower station was decommissioned and hundreds of $\mathrm{km}$ of upstream tributaries became available for migratory fish. In the first autumn after the change (2010), Atlantic salmon had already reclaimed their habitat, which had been lost for $60 \mathrm{yr}$, and at the opening of the season on 1 April 2011, 2 spring salmon were caught in the restored river stretch. Based on previous experience, we are certain that sea-trout and salmon will swiftly utilize the new areas, but it remains an open question how far NSH will venture upstream, even with free passage. It is important that the adults move up and spawn far enough from the sea to ensure a slow descent of juveniles to enable them to reach the critical size before entry into salt water. Monitoring during the coming years will reveal whether NSH have benefitted substantially from the restoration, but there is already some evidence that other species, and indeed the entire ecosystem, have benefitted from the re-establishment of riverine connectivity.

\section{LITERATURE CITED}

Anonymous (1997) Laksefiskene og fiskeriet i Vadehavsområdet. Technical report. DFU-rapport 40-97. Danmarks Fiskeriundersøgelser, Copenhagen

Borcherding J, Scharbert A, Urbatzka R (2006) Timing of downstream migration and food uptake of juvenile North Sea houting stocked in the Lower Rhine and the Lippe (Germany). J Fish Biol 68:1271-1286

Borcherding J, Pickhardt C, Winter HV, Becker JS (2008) Migration history of North Sea houting (Coregonus oxyrinchus L.) caught in Lake IJsselmeer (The Netherlands) inferred from scale transects of $88 \mathrm{Sr}: 44 \mathrm{Ca}$ ratios. Aquat Sci 70:47-56

Borcherding J, Heynen M, Jäger-Kleinicke T, Winter HV, Eckmann R (2010) Re-establishment of the North Sea houting in the River Rhine. Fish Manag Ecol 17:291-293

De Groot SJ, Nijssen H (1997) The North Sea houting, Coregonus oxyrinchus, back in the Netherlands (Pisces, Salmoniformes, Salmonidae). Bull Zool Mus Univ Amst 16:21-24

Grøn P (2005) Undersøgelse af snæbelbestanden i Vidåsystemet og Brede $\AA$ 2005. Report for the County of Southern Jutland. Sønderjullands Amt, Tønder

> Hansen MM, Mensberg KLD, Berg S (1999) Postglacial recolonization patterns and genetic relationships among whitefish (Coregonus sp.) populations in Denmark, inferred from mitochondrial DNA and microsatellite markers. Mol Ecol 8:239-252

> Hansen MM, Nielsen EE, Mensberg KLD (2006) Underwater but not out of sight: genetic monitoring of effective population size in the endangered North Sea houting (Coregonus oxyrinchus). Can J Fish Aquat Sci 63: 780-787

Hansen MM, Fraser DJ, Als TD, Mensberg KLD (2008) Reproductive isolation, evolutionary distinctiveness and setting conservation priorities: the case of European lake whitefish and the endangered North Sea houting (Coregonus spp.). BMC Evol Biol 8:137

Jensen AR, Nielsen HT, Ejbye-Ernst M (2003) National management plan for the houting. Ministry of the Environment, Forest and Nature Agency, County of Southern Jutland and County of Ribe, Ribe

Kranenbarg J, Winter HV, Backx JJGM (2002) Recent increase of North Sea houting and prospects for recolonization in the Netherlands. J Fish Biol 61(Suppl A): 251-253

Madsen SS, Larsen BK, Jensen FB (1996) Effects of freshwater to seawater transfer on osmoregulation, acid-base balance and respiration in river migrating whitefish 
(Coregonus lavaretus). J Comp Physiol B Biochem Syst Environ Physiol 166:101-109

Muus BJ, Dahlstrøm P (1990) Europas ferskvandsfisk. Gads Forlag, Copenhagen

> Poulsen SB, Svendsen JC, Jensen LF, Schulz C, JägerKlienicke T, Schwarten H (2010) Effects of food depriva-

Editorial responsibility: Steven Cooke, Ottawa, Ontario, Canada tion on refuge use and dispersal in juvenile North Sea houting under experimental conditions. J Fish Biol 77 : 1702-1708

Rasmussen PC (2004) Opvækstområder for snæbel i Vidå og Ribe Å. County of Sønderjylland, County of Ribe, and Forest and Nature Agency, Ribe

Submitted: April 19, 2011; Accepted: September 30, 2011 Proofs received from author(s): January 3, 2012 